\title{
THE METHODS OF SELECTION OF THE PROJECT MANAGEMENT METHODOLOGY
}

\author{
Igor Kononenko, Anna Kharazii \\ Strategic Management Department, National Technical University "Kharkiv Politechnic Institute", \\ 21, Frunze str., Kharkiv, 61002, Ukraine, \\ igorvkononenko@gmail.com
}

\begin{abstract}
The problem of selecting the methodology to manage the company's projects or a specific project is reviewed. The authors suggest the methods to select methodology that are designated for application under different conditions of awareness of a decision-maker about the existing methodologies, their advantages and weaknesses and about the range of efficient use.

As the methods are more precise, they require a more laborious analysis of the project and its environment. It is proposed to make the most substantiated choice resulting from solution of the task on optimizing the project's scope to the following criteria: profit, time, cost, quality, risk, and a company's maturity growth. Copyright $\mathbb{C}$ Research Institute for Intelligent Computer Systems, 2014. All rights reserved.
\end{abstract}

Keywords: project management, selection, methodology, optimization, profit, cost, time, quality, risk, maturity.

\section{INTRODUCTION}

Before starting managing any project, the problem of choosing adequate methodology arises. Nowadays, there are plenty of project management methodologies, such as ISO 21500 standard, PMBoK, PRINCE2, P2M, RUP, Agile methodologies and many others.

The selection of the adequate project management methodology is a challenging issue as for project manager concerning an individual project, as well as for the whole company concerning managing all its projects. The selected project management methodology has a great impact on the personnel development programs, purchase of software necessary for managing the business, the set of business process, and even on the organizational structure of the company together with the department regulations and job descriptions.

In practice, project manager or company management do not always have a clear understanding of all existing variants of standards and project management methodologies, considering only limited number of options. In this case the specifics of the company or the project are not taken into account. The resolution of this issue requires rather deep knowledge of a particular methodology or standard and the approaches to their selection.

The methods which would constitute a totality of approaches and operations applicable at various levels of managers training, with different degrees of awareness about the project and its environment are necessary for practical application.

Aim of the paper is creation of methods to select the methodology to manage the project, with different degrees of awareness of the project manager about the methodologies and with different potentials of the project and its environment analysis.

\section{ANALYSIS OF RECENT RESEARCHES AND REFERENCES}

A. Cockburn [1] describes important factors that must be taken into account when selecting the project management methodology.

B. Boehm, R. Turner [2, 3] suggested a method of balancing between the rigid planned methodologies and Agile methodologies while managing a specific project in the expected environment. The method's essence lies in the following stages.

Stage 1 . They evaluate the risks connected with project's implementation through use of the planned and Agile methodologies according to specific environment conditions.

Stage 2. If the risks related to application of Agile methodology prevail over the ones inherent to the planned methodology, the latter should be applied. 
Stage 3. If the risks related to application of the planned methodology prevail over the risks inherent to Agile methodology, they should apply Agile methodology.

Stage 4. If some components of the project meet the stage 2 , and others meet the stage 3 , the most adequate methodologies will be applied to the outlined components.

Stage 5. They map out the project's implementation.

Stage 6. They monitor the project's progress, evaluate the risks and potentials, re-adjust the balance, if necessary.

J. Sheffield, J. Lemétayer [4], by virtue of the reference analysis, point out the factors that have impact upon the choice of methodology to manage the software development project, which is focused on a rigid planned approach (Prince 2, PMBoK) or on the adaptive Agile approach. As well a survey of 127 specialists in the area of project management out of 22 countries has been made in the paper. The total number of respondents has included $26 \%$ of specialists on application of Prince 2, 28\% - on use of PMBoK and $30 \%$ - on Agile. The least project as pointed out by the respondents has been evaluated of USD 2500 and has had the labour intensity of 2 man-months, the largest project's cost has been of USD $840 \mathrm{mln}$ and has had the labour intensity of 1260 man-years. The survey of specialists has been aimed at specifying the factors in the project and its environment testifying to a necessity of application of Agile approach in successful projects intended to creating software products. Following from the survey, the list of prioritized factors has been formed. Low values of such factors denote the planned approach to manage the project, high values highlight Agile approach. The factor analysis has been conducted for four groups of variables characterizing the project's environment, the project, Agility at development of software products and the project's success. Hence 8 most important factors have been outlined.

S. Lazaros, D.C. Prodromos [5] dealt with a survey on performance of 112 projects in the area of software production by 63 companies from Greece. Findings of the survey have been analysed by means structural equations. The analysis has been aimed at examining the effect of the staff quality, quality of processes on the risks of software products projects. The paper reviews 6 risk factors in such projects, in particular: the user, requirements, complexity of the project, planning and control, project team and company's environment. The project's general quality has been measured by means of two factors: quality of processes and staff quality. The analysis has shown that there is a negative statistically significant relation between the quality of the project and the risks. There is a similarly negative relation between the staff quality and five of six risk parameters (except the project's complexity one). As well, a significant negative relation is traced between the quality of processes and the project's team risk factor.

O. McHugh, H. Mairéad in [6] studied the issue of transition organization engaged in creation of software systems to the internationally recognized project management methodology. As exemplified by five Irish companies, the reasons of transition from the corporate methodologies to manage the projects to the internationally accepted ones, and also the reasons of implementing such methodologies in case the company has got no project management methodology at all are reviewed. In one company (with the least number of employees) they have been selecting the methodology based on advice of their colleagues and they have chosen PMBoK. In the second case, selection has also been made according to the advice of colleagues, however with that they have considered the option of tailoring the methodology to meet the company's needs. They have preferred PRINCE 2. The third company has selected the methodology subject to CMMI recommendations in order to pass through certification on that system thereafter. Besides, when selecting the methodology they have relied on the opinion of their US parent structure, which appreciates an option of getting the PMI certificate. It is no wonder that finally they have accepted the PMBoK methodology for application. The fourth company involving about 2500 employees has formed a freestanding team for selecting the methodology. When making the decision, they have taken into account the opportunity of adapting the methodology to meet the company's needs. Eventually they have taken the road to adjust PMBoK. Finally, in the fifth case, the major focus (while selecting a methodology) has been given to availability of plenty of bodies that certify specialists, hold trainings and provide support at implementation of a specific methodology. In addition, allowance has been made to the particular methodology as used in the parent company and to the possibility of adopting the methodology. As a result, the choice was made in favour of the PRINCE 2.

J. Xu, H. Zheng, Z. Zeng, S. Wu, M. Shen [7] dealt with the discrete task of searching for a compromise between time, cost of the project, crashing cost and impact on environment. Time of operations is set as a vague value with a triangle membership function. The adaptive hybrid genetic algorithm is offered for solution of the task. 


\section{SELECTION OF THE PROJECT MANAGEMENT METHODOLOGY BASING ON EXISTING RECOMMENDATIONS}

The method of selecting the project management methodology is suggested. The method is designed for the situations when the project manager and project team do not have a full knowledge of alternative project management methodologies and standards. As a rule, the project manager is familiar enough with one or two methodologies. The knowledge of all the others is rather superficial. In case the team does not have enough time and/or resources for studying alternative methodologies during managing a specific project, it is reasonable to use the existing recommendations about their application under specific practical circumstances. The suggested method serves exactly for accomplishing this purpose.

The given method is a questionnaire for a project manager. This questionnaire was presented in the paper [8]. In the paper the questionnaire was further developed. It consists of two parts. In the first part the short resume of the project is given (table 1). The second part is a set of fixed-choice questions (tables 2-6). They cover a scope of forming of a project team, the level of its expertise, the choice of the means of communication and the ways of reporting, as well as the level of project manager's responsibility, the list of any possible risks and consequences in case ofunsatisfactory project outcome.

The answers to the questions correspond to the scores on the scale from 1 to 4 depending on the level of detail of the project management processes, including the required frequency and thoroughness of the inspection of the project implementation processes. The lower is the score for the questionnaire or the theme blocks, the more control elements the corresponding methodology should include. The total score corresponds to the recommended methodologies, which are the most suitable for managing the project.

Table 1. Brief Project Description.

\begin{tabular}{|l|l|}
\hline \multicolumn{1}{|c|}{ Questions } & \multicolumn{1}{c|}{ Answers } \\
\hline Project name & \multicolumn{1}{|c|}{} \\
\hline $\begin{array}{l}\text { Project } \\
\text { scope }\end{array}$ & $\begin{array}{l}\text { Main strategic project aim. } \\
\text { Brief description of innovation/project }\end{array}$ \\
\hline Project type & $\begin{array}{l}\text { R\&D, creation of new product } \\
\text { (technology, service), creation of new } \\
\text { manufacture }\end{array}$ \\
\hline $\begin{array}{l}\text { Project } \\
\text { product }\end{array}$ & $\begin{array}{l}\text { Brief description of the product, service, } \\
\text { technology, innovation created in the } \\
\text { project }\end{array}$ \\
\hline
\end{tabular}

Table 2. Project Team.

\begin{tabular}{|c|c|c|c|}
\hline Questions & Possible answer & Score & $\begin{array}{l}\text { Recommended } \\
\text { methodology }\end{array}$ \\
\hline \multirow{4}{*}{$\begin{array}{l}\text { Customer's } \\
\text { (investor's) } \\
\text { experience } \\
\text { of working } \\
\text { with this } \\
\text { project } \\
\text { team }\end{array}$} & $\begin{array}{l}\text { Has never worked } \\
\text { with this team }\end{array}$ & 1 & PMBoK \\
\hline & $\begin{array}{l}\text { Worked with some } \\
\text { members of the } \\
\text { team }\end{array}$ & 2 & PMBoK \\
\hline & $\begin{array}{l}\text { Worked with the } \\
\text { project team leader }\end{array}$ & 3 & $\begin{array}{l}\text { SCRUM, } \\
\text { PMBoK }\end{array}$ \\
\hline & $\begin{array}{l}\text { One or more } \\
\text { common projects } \\
\text { with the whole } \\
\text { project team }\end{array}$ & 4 & SCRUM \\
\hline
\end{tabular}

Table 3. Evaluation of the Project Team's Expertise by the Project Manager.

\begin{tabular}{|c|c|c|c|}
\hline Questions & Possible answer & Score & $\begin{array}{c}\text { Recommended } \\
\text { methodology }\end{array}$ \\
\hline \multirow{4}{*}{$\begin{array}{l}\text { Work } \\
\text { experi- } \\
\text { ence in } \\
\text { the given } \\
\text { field }\end{array}$} & $\begin{array}{l}\text { No work } \\
\text { experience. }\end{array}$ & 1 & PMBoK \\
\hline & $\begin{array}{l}\text { Experience of } \\
\text { working in the } \\
\text { field for less than } 2 \\
\text { years }\end{array}$ & 2 & $\begin{array}{c}\text { SCRUM*, } \\
\text { PMBoK }\end{array}$ \\
\hline & $\begin{array}{l}\text { Experience of } \\
\text { working in the } \\
\text { field from } 2 \text { to } 5 \\
\text { years }\end{array}$ & 3 & SCRUM \\
\hline & $\begin{array}{l}\text { Experience of } \\
\text { working in the } \\
\text { field for more than } \\
5 \text { years }\end{array}$ & 4 & SCRUM \\
\hline \multirow{4}{*}{$\begin{array}{l}\text { Under- } \\
\text { standing } \\
\text { of } \\
\text { require- } \\
\text { ments, } \\
\text { adapting } \\
\text { ability, } \\
\text { initiative }\end{array}$} & $\begin{array}{l}\text { Almost do not } \\
\text { understand the } \\
\text { requirements; } \\
\text { require frequent } \\
\text { explanations and } \\
\text { constant control }\end{array}$ & 1 & PMBoK \\
\hline & $\begin{array}{l}\text { Understand the } \\
\text { requirements, can } \\
\text { follow them, but } \\
\text { require regular } \\
\text { control }\end{array}$ & 2 & PMBoK \\
\hline & $\begin{array}{l}\text { Understand the } \\
\text { requirements, can } \\
\text { follow them, do } \\
\text { not require regular } \\
\text { control }\end{array}$ & 3 & SCRUM \\
\hline & $\begin{array}{l}\text { Have good } \\
\text { understanding of } \\
\text { the requirements; } \\
\text { can follow them } \\
\text { without regular } \\
\text { control; can } \\
\text { suggest better } \\
\text { alternatives }\end{array}$ & 4 & SCRUM \\
\hline \multirow{2}{*}{$\begin{array}{l}\text { Experi- } \\
\text { ence of } \\
\text { coopera- }\end{array}$} & $\begin{array}{l}\text { Have never } \\
\text { worked together }\end{array}$ & 1 & PMBoK \\
\hline & Worked together & 2 & SCRUM*, \\
\hline
\end{tabular}




\begin{tabular}{|c|c|c|c|}
\hline Questions & Possible answer & Score & $\begin{array}{c}\text { Recommended } \\
\text { methodology }\end{array}$ \\
\hline \multirow[t]{4}{*}{ tion } & $\begin{array}{l}\text { on the creation of a } \\
\text { product, but in the } \\
\text { different field }\end{array}$ & & PMBoK \\
\hline & $\begin{array}{l}\text { Worked together } \\
\text { on the creation of a } \\
\text { product, but in the } \\
\text { different field }\end{array}$ & 2 & $\begin{array}{c}\text { SCRUM* } \\
\text { PMBoK }\end{array}$ \\
\hline & $\begin{array}{l}\text { Worked together } \\
\text { on the creation of } \\
\text { one product in a } \\
\text { field of interest. }\end{array}$ & 3 & SCRUM \\
\hline & $\begin{array}{l}\text { Worked together } \\
\text { on the creation of } \\
\text { several projects in } \\
\text { the field of interest }\end{array}$ & 4 & SCRUM \\
\hline \multirow[t]{4}{*}{$\begin{array}{l}\text { Knowl- } \\
\text { edge of } \\
\text { applied } \\
\text { tools and } \\
\text { methods }\end{array}$} & $\begin{array}{l}\text { Tools and } \\
\text { methods, applied } \\
\text { in the given } \\
\text { project, have never } \\
\text { been used before } \\
\text { and are unknown } \\
\text { to the team }\end{array}$ & 1 & PMBoK \\
\hline & $\begin{array}{l}\text { Tools and } \\
\text { methods, applied } \\
\text { in the project, are } \\
\text { known to the team } \\
\text { but have never } \\
\text { been used before }\end{array}$ & 2 & $\begin{array}{c}\text { SCRUM* } \\
\text { PMBoK }\end{array}$ \\
\hline & $\begin{array}{l}\text { Tools and } \\
\text { methods, used in } \\
\text { the project, are } \\
\text { known to the team, } \\
\text { but are rarely used }\end{array}$ & 3 & SCRUM \\
\hline & $\begin{array}{l}\text { Tools and methods } \\
\text { are known to the } \\
\text { team and have } \\
\text { been widely used } \\
\text { before }\end{array}$ & 4 & SCRUM \\
\hline \multirow[t]{4}{*}{$\begin{array}{l}\text { Learning } \\
\text { ability }\end{array}$} & $\begin{array}{l}\text { It is hard for the } \\
\text { team to learn new } \\
\text { knowledge and } \\
\text { technologies, and } \\
\text { to adjust to } \\
\text { changes }\end{array}$ & 1 & PMBoK \\
\hline & $\begin{array}{l}\text { For some members } \\
\text { of the team it is } \\
\text { hard to learn new } \\
\text { information and } \\
\text { technologies, but } \\
\text { the team can adjust } \\
\text { to changes }\end{array}$ & 2 & PMBoK \\
\hline & $\begin{array}{l}\text { Easily absorb new } \\
\text { knowledge, can } \\
\text { adjust to changes }\end{array}$ & 3 & SCRUM \\
\hline & $\begin{array}{l}\text { The team can } \\
\text { easily absorb } \\
\text { information, } \\
\text { always tries to } \\
\text { learn something }\end{array}$ & 4 & SCRUM \\
\hline
\end{tabular}

\begin{tabular}{|c|c|c|c|}
\hline Questions & Possible answer & Score & $\begin{array}{c}\text { Recommended } \\
\text { methodology }\end{array}$ \\
\hline & $\begin{array}{l}\text { new; can well } \\
\text { adjust to the } \\
\text { changes }\end{array}$ & & \\
\hline \multirow{4}{*}{$\begin{array}{l}\text { Team's } \\
\text { ability to } \\
\text { clearly } \\
\text { formulate } \\
\text { and } \\
\text { openly } \\
\text { express } \\
\text { ideas }\end{array}$} & $\begin{array}{l}\text { Can't clearly } \\
\text { formulate ideas } \\
\text { and rarely express } \\
\text { them }\end{array}$ & 1 & PMBoK \\
\hline & $\begin{array}{l}\text { Can clearly } \\
\text { formulate their } \\
\text { ideas but rarely } \\
\text { express them } \\
\end{array}$ & 2 & PMBoK \\
\hline & $\begin{array}{l}\text { Can clearly } \\
\text { formulate their } \\
\text { ideas and openly } \\
\text { express them }\end{array}$ & 3 & SCRUM \\
\hline & $\begin{array}{l}\text { Can clearly } \\
\text { formulate, openly } \\
\text { express and justify } \\
\text { their ideas }\end{array}$ & 4 & SCRUM \\
\hline \multirow[t]{4}{*}{$\begin{array}{l}\text { Ability to } \\
\text { admit } \\
\text { mistakes }\end{array}$} & $\begin{array}{l}\text { Don't admit } \\
\text { making mistakes } \\
\text { and can't learn } \\
\text { from them } \\
\end{array}$ & 1 & PMBoK \\
\hline & $\begin{array}{l}\text { Rarely admit their } \\
\text { mistakes but try to } \\
\text { never make them } \\
\text { again }\end{array}$ & 2 & PMBoK \\
\hline & $\begin{array}{l}\text { Openly admit } \\
\text { making mistakes } \\
\text { and try to never } \\
\text { make them again }\end{array}$ & 3 & SCRUM \\
\hline & $\begin{array}{l}\text { Openly admit } \\
\text { making mistakes } \\
\text { and always learn } \\
\text { from them }\end{array}$ & 4 & SCRUM \\
\hline
\end{tabular}

Table 4. Reporting.

\begin{tabular}{|c|c|c|c|}
\hline Questions & Possible answer & Score & $\begin{array}{l}\text { Recommended } \\
\text { methodology }\end{array}$ \\
\hline \multirow{4}{*}{$\begin{array}{l}\text { Means of } \\
\text { communi- } \\
\text { cation }\end{array}$} & $\begin{array}{l}\text { Written reports. Formal } \\
\text { record-keeping }\end{array}$ & 1 & PMBoK \\
\hline & $\begin{array}{l}\text { Voice communication } \\
\text { (telephone connection, } \\
\text { Internet-conference) }\end{array}$ & 2 & SCRUM* \\
\hline & $\begin{array}{l}\text { On-line } \\
\text { communication (ICQ, } \\
\text { E-mail) }\end{array}$ & 3 & SCRUM \\
\hline & $\begin{array}{l}\text { Direct communication } \\
\text { (meetings, video confe- } \\
\text { rences) }\end{array}$ & 4 & SCRUM \\
\hline \multirow{4}{*}{$\begin{array}{l}\text { Frequency } \\
\text { of } \\
\text { reporting to } \\
\text { the } \\
\text { Customer }\end{array}$} & $\begin{array}{l}\text { Reports on every } \\
\text { operation }\end{array}$ & 1 & PMBoK \\
\hline & $\begin{array}{l}\text { Reports on completing } \\
\text { the blocks of work }\end{array}$ & 2 & $\begin{array}{l}\text { SCRUM, } \\
\text { PMBoK }\end{array}$ \\
\hline & $\begin{array}{l}\text { Reports on the } \\
\text { readiness of a } \\
\text { component of project's } \\
\text { product }\end{array}$ & 3 & SCRUM \\
\hline & Reports about project & 4 & SCRUM \\
\hline
\end{tabular}




\begin{tabular}{|l|l|c|c|}
\hline Questions & \multicolumn{1}{|c|}{ Possible answer } & Score & $\begin{array}{l}\text { Recommended } \\
\text { methodology }\end{array}$ \\
\hline & finish & & \\
\hline $\begin{array}{l}\text { Under- } \\
\text { standing } \\
\text { the scope } \\
\text { of works }\end{array}$ & $\begin{array}{l}\text { There is a full list of } \\
\text { works; further } \\
\text { alternation is } \\
\text { impossible }\end{array}$ & 1 & PMBoK \\
\cline { 2 - 4 } & $\begin{array}{l}\text { There is a detailed list } \\
\text { of works, further } \\
\text { alternation is possible }\end{array}$ & 2 & PMBoK \\
\cline { 2 - 4 } & $\begin{array}{l}\text { There is an } \\
\text { approximate list of } \\
\text { project works }\end{array}$ & 3 & SCRUM \\
\cline { 2 - 4 } & $\begin{array}{l}\text { The team understands } \\
\text { the project goal and } \\
\text { several ways for its } \\
\text { achievement }\end{array}$ & 4 & SCRUM \\
\hline
\end{tabular}

Table 5. Project Manager's Responsibility and Main Requirements to the Project.

\begin{tabular}{|c|c|c|c|}
\hline Questions & Possible answer & Score & \begin{tabular}{|c|}
$\begin{array}{c}\text { Recommended } \\
\text { methodology }\end{array}$ \\
\end{tabular} \\
\hline \multirow{4}{*}{$\begin{array}{l}\text { Conse- } \\
\text { quences in } \\
\text { case of } \\
\text { unsatis- } \\
\text { factory } \\
\text { project } \\
\text { outcome }\end{array}$} & Loss of life & 1 & PMBoK \\
\hline & $\begin{array}{l}\text { Loss of irreplaceable } \\
\text { sum of money }\end{array}$ & 2 & $\begin{array}{l}\text { SCRUM*, } \\
\text { PMBoK }\end{array}$ \\
\hline & $\begin{array}{l}\text { Loss of insignificant } \\
\text { sum of money }\end{array}$ & 3 & SCRUM \\
\hline & $\begin{array}{l}\text { Loss of comfort in } \\
\text { work }\end{array}$ & 4 & SCRUM \\
\hline \multirow[t]{4}{*}{ Project cost } & More than $1 \mathrm{mln} . \$$ & 1 & PMBoK \\
\hline & $\begin{array}{l}\text { From } 300 \text { thousand }-1 \\
\text { mln. } \$\end{array}$ & 2 & $\begin{array}{l}\text { SCRUM* } \\
\text { PMBoK }\end{array}$ \\
\hline & $\begin{array}{l}\text { From } 100-300 \\
\text { thousand } \$\end{array}$ & 3 & $\begin{array}{l}\text { SCRUM } \\
\text { PMBoK* }^{*}\end{array}$ \\
\hline & $\begin{array}{l}\text { Less than } 100 \\
\text { thousand \$ }\end{array}$ & 4 & SCRUM \\
\hline \multirow{4}{*}{$\begin{array}{l}\text { Require- } \\
\text { ments to } \\
\text { the project } \\
\text { quality }\end{array}$} & $\begin{array}{l}\text { Highest international } \\
\text { requirements }\end{array}$ & 1 & PMBoK \\
\hline & $\begin{array}{l}\text { International } \\
\text { requirements }\end{array}$ & 2 & $\begin{array}{l}\text { SCRUM*, } \\
\text { PMBoK }\end{array}$ \\
\hline & National requirements & 3 & SCRUM* \\
\hline & Local requirements & 4 & SCRUM \\
\hline \multirow{4}{*}{$\begin{array}{l}\text { Require- } \\
\text { ments to } \\
\text { the } \\
\text { realiza-tion } \\
\text { period of } \\
\text { the project } \\
\end{array}$} & $\begin{array}{l}\text { The period is } \\
\text { unlimited }\end{array}$ & 1 & PMBoK \\
\hline & Not very urgent & 2 & $\begin{array}{l}\text { SCRUM*, } \\
\text { PMBoK }\end{array}$ \\
\hline & Urgent & 3 & SCRUM \\
\hline & Very urgent & 4 & SCRUM \\
\hline \multirow{4}{*}{$\begin{array}{l}\text { Requireme } \\
\text { nts to the } \\
\text { precise } \\
\text { compli- } \\
\text { ance with a } \\
\text { deadline }\end{array}$} & $\begin{array}{l}\text { The deadline should } \\
\text { be strictly met }\end{array}$ & 1 & PMBoK \\
\hline & $\begin{array}{l}\text { Insignificant deviation } \\
\text { from the deadline is } \\
\text { allowed }\end{array}$ & 2 & PMBoK \\
\hline & $\begin{array}{l}\text { Considerable deviation } \\
\text { from the deadline is } \\
\text { allowed }\end{array}$ & 3 & SCRUM \\
\hline & $\begin{array}{l}\text { Compliance with the } \\
\text { deadline is not strictly } \\
\text { required }\end{array}$ & 4 & SCRUM \\
\hline
\end{tabular}

Table 6. Risks Probability.

\begin{tabular}{|c|c|c|c|}
\hline Questions & Possible answer & Score & $\begin{array}{l}\text { Recommended } \\
\text { methodology }\end{array}$ \\
\hline \multirow{4}{*}{$\begin{array}{l}\text { Probability of } \\
\text { occurrence of } \\
\text { technical, } \\
\text { manufacturing } \\
\text { or qualitative } \\
\text { risks }\end{array}$} & $\begin{array}{l}\text { Risk will most } \\
\text { probably occur } \\
(95 \%)\end{array}$ & 1 & PMBoK \\
\hline & $\begin{array}{l}\text { Risk is highly } \\
\text { likely to occur } \\
(75 \%)\end{array}$ & 2 & PMBoK \\
\hline & $\begin{array}{l}\text { Probability of risk } \\
\text { occurrence is } \\
\text { equal }(50 \%)\end{array}$ & 3 & SCRUM* \\
\hline & $\begin{array}{l}\text { Risk is not likely } \\
\text { to occur }(10 \%)\end{array}$ & 4 & SCRUM \\
\hline \multirow{4}{*}{$\begin{array}{l}\text { Probability of } \\
\text { occurrence of } \\
\text { external risks } \\
\text { (disruption of } \\
\text { work by con- } \\
\text { tractors, unfa- } \\
\text { vorable political, } \\
\text { economic } \\
\text { situation in the } \\
\text { country, market } \\
\text { changes, etc.) }\end{array}$} & $\begin{array}{l}\text { Risk will most } \\
\text { probably occur } \\
(95 \%)\end{array}$ & 1 & PMBoK \\
\hline & $\begin{array}{l}\text { Risk is highly } \\
\text { likely to occur } \\
(75 \%)\end{array}$ & 2 & PMBoK \\
\hline & $\begin{array}{l}\text { Probability of risk } \\
\text { occurrence is } \\
\text { equal }(50 \%)\end{array}$ & 3 & SCRUM \\
\hline & $\begin{array}{l}\text { Risk is not likely } \\
\text { to occur }(10 \%)\end{array}$ & 4 & SCRUM \\
\hline \multirow{4}{*}{$\begin{array}{l}\text { Probability of } \\
\text { occurrence of } \\
\text { organizational } \\
\text { risks (disruption } \\
\text { of funding, } \\
\text { delivery of } \\
\text { resources, } \\
\text { inaccurate } \\
\text { prioritizing, etc.) }\end{array}$} & $\begin{array}{l}\text { Risk will most } \\
\text { probably occur } \\
(95 \%)\end{array}$ & 1 & PMBoK \\
\hline & $\begin{array}{l}\text { Risk is highly } \\
\text { likely to occur } \\
(75 \%)\end{array}$ & 2 & PMBoK \\
\hline & $\begin{array}{l}\text { Probability of risk } \\
\text { occurrence is } \\
\text { equal }(50 \%)\end{array}$ & 3 & SCRUM \\
\hline & $\begin{array}{l}\text { Risk is not likely } \\
\text { to occur }(10 \%)\end{array}$ & 4 & SCRUM \\
\hline \multirow{4}{*}{$\begin{array}{l}\text { Probability of } \\
\text { occurrence of } \\
\text { managerial risks } \\
\text { (inefficient } \\
\text { planning, } \\
\text { controlling, } \\
\text { communication } \\
\text { problems, etc.) }\end{array}$} & $\begin{array}{l}\text { Risk will most } \\
\text { probably occur } \\
(95 \%)\end{array}$ & 1 & PMBoK \\
\hline & $\begin{array}{l}\text { Risk is highly } \\
\text { likely to occur } \\
(75 \%)\end{array}$ & 2 & PMBoK \\
\hline & $\begin{array}{l}\text { Probability of risk } \\
\text { occurrence is } \\
\text { equal }(50 \%)\end{array}$ & 3 & SCRUM \\
\hline & $\begin{array}{l}\text { Risk is not likely } \\
\text { to occur }(10 \%)\end{array}$ & 4 & SCRUM \\
\hline
\end{tabular}

The cases, when application of the methodology is not stipulated by the situation but is still possible, are marked with the sign "*”".

In the tables 1-6 the recommendations about application of two alternative methodologies PMBoK and SCRUM - are given.

At this stage two existing methodologies, which are completely different in their approach to project management, have been analyzed. The choice of methodologies was stipulated by the intent to provide the most graphic example of application of 
two alternative approaches to managing a single project. On the one hand, it is the PMBoK Standard, which contains 47 project management processes; and on the other hand - it is SCRUM, a framework methodology, which has been widely used for managing IT projects in Ukraine. The version of the questionnaire set out in this paper, is used to select a project management methodology namely in the field of IT.

Based on the obtained recommendations, the project manager can choose the most reasonable methodology regarding the given project. The selection process can be rather difficult, especially when the scores for separate blocks of the questionnaire suggest different methodologies. In such case project manager should make a choice based on the majority of recommendations and his own preferences. If the methodology is being selected by the company management for several perspective projects, among these project the most standard ones should be considered. Then the questionnaire, which is the first method, should be completed for all standard perspective projects and make a choice based on recommendations.

\section{SELECTION OF PROJECT MANAGEMENT METHODOLOGY FROM PERSPECTIVE OF MAN-HOURS, MANAGEMENT COST AND RELATED RISKS}

The second method is designed for the situations when the project team has sufficient knowledge of the alternative project management methodologies, and when it also has time and resources for evaluating the expenses and man hours regarding usage of each methodology as well the risks it may provoke. [8]

The given method suggests the solution for the three-criteria optimization problem of selecting a methodology with regard to the constraints. The optimization criteria are: the work content of managing a project with the methodology under study; the cost of management, the risks related to managing the project with the methodology under study.

The algorithm of work content and cost evaluation of a methodology consists of several stages.

1. Analysis of project management methodology - how the project is handled, which processes need to be completed, to what extent the project team members are involved into managing the project.

2. Creation of a list of project manager's activities in terms of the given methodology. At this stage all processes, which may require involvement of the project manager both at the preparation stage, and during execution, have to be taken into account.

3. Calculation of project manager's man-hours, required for managing the project.

4. Identification of the processes, which may require involvement of other project team members and to what extent it may happen. For example, reporting or development activities almost always require participation of not only the project manager, but the whole project team.

5. Calculation of each team member's manhours, required for managing the project.

6. Define general man-hours of project management.

7. Calculation of project management cost with the help of the following formula:

$$
C_{M}=M \cdot P+\sum_{i=1}^{m} H_{i} \cdot W_{i}+\sum_{j=1}^{n} C_{j} \cdot K_{j}
$$

where $M$ - project manager's hourly wage rate; $P$ - project manager's man-hours; $H_{i}$ - hourly wage rate of an i-th project manager's assistant. An assistant can be represented by a business-consultant or any other professional, involved to managing the project; $W_{i}-$ man-hours of an i-th assistant; $C_{j}$. hourly wage rate of a j-th team member; $K_{j}$ - manhours of a j-th team member; $m$ - quantity of project manager assistants; $n$ - quantity of project team members.

8. To estimate the risks connected with the project management through use of the methodology under assessment.

Further, one should prioritize the methodologies in question subject to three criteria and choose the best one.

Restrictions on the cost of management process and on labour input thereof can be taken into account in the course of optimization.

\section{OPTIMIZATION OF THE PROJECT SCOPE}

When solving the task of selecting the project scope, the choice of methodology to be used for management of such project is a vital fact. The applicable methodology of project management tells on time of its implementation, cost, quality of products, stages and the entire project as a whole, on the risks associated with it. Solving the objective of optimizing the project scope for alternative methodologies, one can choose it more substantially than it does with a methodology in isolation from 
optimization of the project scope. In this paper the choice of a methodology is proposed to do by solving the optimization problem for the project scope by criteria profit, time, cost, quality, risk.

In cases when it is acceptable in terms of studies complexity, such optimization can be performed for all the methodologies and optimization by the criteria: the work content of managing a project, the cost, the risks of the project as described above, can be avoided.

In order to reduce the labour intensity of the research, it is expedient to make a pre-selection of a small number of methodologies, for example two alternatives, by means of the previous method. As soon as the list of methodologies is narrowed, one can optimize the project scope provided that each of the left methodologies is applied.

For solving the objective of optimizing the project scope according to the criteria: profit, time, cost, quality, risks it is possible to use the method of implicit enumeration in combination with the generalized criterion or the method of successive concessions as described in the paper [9].

The project scope optimization under the successive concessions method is advantageous if compared with the application of the generalized criterion. It is not necessary to set weighting factors for each of the criteria, it is always difficult. It suffices only to prioritize the criteria from the point of view of the task to be solved and to specify the admissible concessions.

\section{OPTIMIZING THE SELECTION OF PROJECT MANAGEMENT METHODOLOGY AND PROJECT SCOPE, TAKING INTO ACCOUNT CHANGES IN THE MATURITY OF THE COMPANY}

The selected methodology of project management tells on the company's maturity degree. Thus, while estimating the company's maturity by means of CMMI model [10], they make it clear if the company applies the standard project management processes, as well as the standard processes in production activities, whether the archives for the performed projects and actions of the company are kept, which methods of feedback are used, whether there is a continuous improvement of processes. The project scope as well as the applicable methodology to manage it, with the chosen depth and integrity of application, affects the change of the company's maturity degree.

For the projects that are managed through use of the selected alternative methodologies and the scope of which is optimized according to the criteria: profit, time, cost, quality, risks, the estimation is made towards the company's maturity change to be gained in response. At this time there is a chance to make a final selection of methodology out of alternatives based on comparison of values of six criteria: profit, time, cost, quality, risks and maturity of the company.

The choice shall be made by the company's representatives in terms of the strategic goals of its development.

\section{CONCLUSIONS}

The paper introduces methods to select the project management methodology that are designated for application under the conditions of different degrees of awareness of the decisionmaker. The first method presupposes that the project manager fills in the questionnaire. Depending on his replies, this or that methodology is recommended for use. The second method is dedicated to assessment of labour intensity of the project management by means of the methodologies in question, cost of management and risks. Further, one resolves the triple-criteria task of optimization for selecting the best methodology.

The most precise choice of methodology is based on optimizing the project scope provided that a specific methodology is applied. For this purpose, subject to application of one of the simple methods, by means of which the list of suggested methodologies is narrowed to a small number, it is supposed to optimize the project scope subject to five criteria: profit, cost, time, quality, risks. Thereafter, one makes an estimation of change of the company's maturity while implementing the project on the chosen methodologies by means of CMMI model or any other maturity model in line with the relevant specificity of the company's activity. Selection of the best alternative to implement the project when using this or that methodology so far subject to six criteria: profit, cost, time, quality, risks and maturity, takes place at the next stage.

\section{REFERENCES}

[1] A. Cockburn, Methodology per Project, Humans and Technology Technical Report HaT TR, 4 December 1999.

[2] B. Boehm, R. Turner, Using risk to balance agile and plan-driven methods, IEEE Computer Society, (36) 6 (2003), pp. 57-66.

[3] B. Boehm, R. Turner, Balancing Agility and Discipline: A Guide for the Perplexed, Addison-Wesley, Boston, MA, 2004.

[4] J. Sheffield, J. Lemétayer, Factors associated with the software development agility of successful projects, International Journal of Project Management, (31) 2 (2013), pp. 459-472. 
[5] S. Lazaros, D. C. Prodromos, Quality vs risk: An investigation of their relationship in software development projects, International Journal of Project Management, (32) 6 (2014), pp. 1073-1082.

[6] O. McHugh, H. Mairéad, Investigating the rationale for adopting an internationallyrecognised project2 management methodology in Ireland: The view of the project manager, International Journal of Project Management (29) 5 (2011), pp. 637-646.

[7] J. Xu, H. Zheng, Z. Zeng, S. Wu, M. Shen, Discrete time-cost-environment trade-off problem for large-scale construction systems with multiple modes under fuzzy uncertainty and its application to Jinping-II Hydroelectric Project, International Journal of Project Management, (30) 8 (2012), pp. 950-966.

[8] I. Kononenko, A. Kharazii, N. Iranik, Selection method of the project management methodology and its application, in Proceedings of the $7^{\text {th }}$ IEEE International Conference on Intelligent Data Acquisition and Advanced Computing Systems: Technology and Applications (IDAACS'2013), Berlin, Germany, (12-14 September 2013), pp. 578-582.

[9] I. V. Kononenko, E. V. Lobach, A. V. Kharazii, Multi-criteria optimization of content for a given project priorities for criteria, Open Information and Computer Integrated Technologies: Transactions of National Aerospace University "HAI", (59) (2013), pp. 6-13. (in Russian)

[10] CMMI for Development, Version 1.3, Software Engineering Institute, Carnegie Mellon University, 2010.

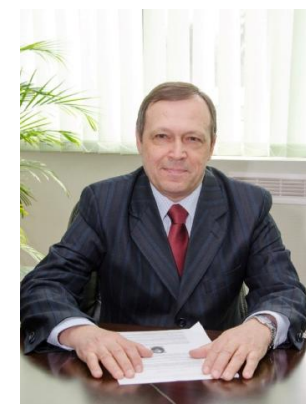

Igor V. Kononenko - Professor, Doctor of Technical Sciences, Laureate of the State Prize of Ukraine, Head of the Strategic Management Department of National Technical University "Kharkiv Polytechnic Institute", National Expert of UNIDO (1995-1996), Deputy Director of Institute of Machinery and Systems of the Ministry of Industrial Policy and National Academy of Sciences of Ukraine (1993-2002), an expert in forecasting and management of the development of socio-economic systems. Under his direction a computerized simulation models of the socio-economic development of Ukraine has been developed. Author of more than 220 scientific works, 7 books on forecasting, strategic and project management.

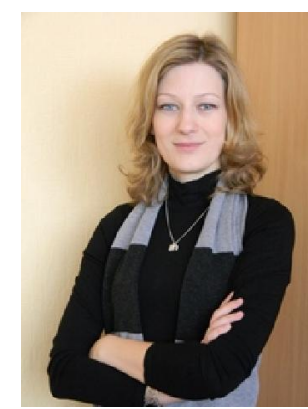

Anna Kharazii - Master of science in Project Management, a graduate of Strategic Management Department of National Technical University "Kharkiv Polytechnic Institute", since 2013 - a postgraduate student in the same department. Engaged in research of optimization problems of project management, and studied the influence of methodologies on project characteristics. Since 2010 she is a coordinator of the annual international conference "INTEGRATED MANAGEMENT». She is an author of 10 scientific publications. 